\title{
Relationships of Native and Exotic Strains of Phragmites Australis to Wetland Ecosystem Properties
}

John Kelly

Loyola University Chicago, jkelly7@luc.edu

\author{
L. A. Volesky \\ Northeastern Illinois University \\ S. Iqbal \\ Loyola University Chicago \\ P. Geddes \\ Northeastern Illinois University
}

Follow this and additional works at: https://ecommons.luc.edu/biology_facpubs

Part of the Biology Commons

Author Manuscript

This is a pre-publication author manuscript of the final, published article.

\section{Recommended Citation}

Kelly, John; Volesky, L. A.; Iqbal, S.; and Geddes, P.. Relationships of Native and Exotic Strains of Phragmites Australis to Wetland Ecosystem Properties. Wetlands, 38, 3: 577-589, 2018. Retrieved from Loyola eCommons, Biology: Faculty Publications and Other Works, http://dx.doi.org/10.1007/ s13157-018-1001-1

This Article is brought to you for free and open access by the Faculty Publications and Other Works by Department at Loyola eCommons. It has been accepted for inclusion in Biology: Faculty Publications and Other Works by an authorized administrator of Loyola eCommons. For more information, please contact ecommons@luc.edu. c) (i) $\Theta$

This work is licensed under a Creative Commons Attribution-Noncommercial-No Derivative Works 3.0 License. (c) Society of Wetland Scientists, 2018. 
RELATIONSHIPS OF NATIVE AND EXOTIC STRAINS OF PHRAGMITES AUSTRALIS TO WETLAND ECOSYSTEM PROPERTIES

4

1. Department of Biology, Northeastern Illinois University, 5500 N. St. Louis Ave, Chicago, IL 60625

2. Department of Biology, Loyola University Chicago, 1032 W. Sheridan Rd, Chicago, IL 60660

\section{ABSTRACT}

14 Invasions by exotic plant species like Phragmites australis can affect wetlands and the services

15 they provide, including denitrification. Native and exotic Phragmites strains were genetically

16 verified in 2002 but few studies have compared their ecosystem effects. We compared

17 relationships between native and exotic Phragmites and environmental attributes, soil nutrient

18 concentrations, and abundance and activity of soil denitrifying bacteria. There were no

19 significant differences for any measured variables between sites with exotic and native strains.

20 However, there were significant positive correlations between native Phragmites stem density

21 and soil nutrient concentrations and denitrification rates. Furthermore, denitrifying bacterial

22 abundance was positively correlated with nitrate concentration and denitrification rates.

23 Additionally, there were significant negative correlations between water levels in native 
24 Phragmites sites and native stem density, nutrient concentrations, and denitrification rates.

25 Surprisingly, we found no significant relationships between exotic stem density or water level

26 and measured variables. These results suggest 1) the native strain may have important ecosystem

27 effects that had only been documented for exotic Phragmites, and 2) abiotic drivers such as

28 water level may have mediated this outcome. Further work is needed to determine if the stem

29 density gradients were a consequence, rather than a cause, of pre-existing gradients of abiotic

30 factors.

31 Keywords: Phragmites australis; denitrification; soil nutrients; Phragmites australis subspecies

32 americanus; exotic haplotype $\mathrm{M}$; nirS

\section{INTRODUCTION}

35 Wetlands are important ecosystems because they provide habitat for numerous species

36 and are responsible for essential ecosystem services such as flood abatement and nutrient

37 cycling. For example, wetlands provide ideal conditions for denitrification, a microbially-driven

38 process that can transform excess nitrate from surface and groundwater into gaseous forms of

39 nitrogen (nitrous oxide and nitrogen), thus improving water quality (Zedler 2003). Emergent

40 wetland plants can enhance denitrification by producing high levels of soil organic matter, which

41 provides energy to soil microbes that catalyze denitrification (e.g., Bastviken et al. 2005).

42 Denitrification services provided by natural wetlands have been well documented, and estimates

43 indicate they can remove up to $80 \%$ of nitrate from water (Zedler 2003). 
Wetland degradation and loss because of urbanization and agriculture are important

45 factors that have led to major losses of wetland area worldwide and to the disruption of wetland structure and function (Ehrenfeld 2000, Zedler 2003). Specifically, the invasion of wetlands by

47 exotic plant species can affect ecosystem properties and their ability to perform ecosystem

48 services such as denitrification positively, neutrally, or negatively (Theuerkauf et al. 2017).

49 Several studies have shown that invasive plants can diminish denitrification potential rates (e.g.,

50 Evans et al. 2001, Dassonville et al. 2011, Carey et al. 2017) or enhance them (e.g., Ehrenfeld

51 2003, Zedler 2003, Lishawa et al. 2014). A few studies, however, have documented no change in

52 denitrification potential when comparing soils under exotic and native plant stands (e.g.,

53 Ehernfeld 2003).

Exotic Phragmites australis is one of the four introduced species of concern (which also

55 include Lythrum salicaria, Typha x glauca, and Phalaris arundinacea) that have spread

56 throughout North American temperate wetlands (Galatowitsch et al. 1999). Historically, native

57 Phragmites was found in North America within heterogeneous plant communities in coastal and

58 inland marshes (Meyerson et al. 2009). By the 1970s, however, the presence of extensive

59 Phragmites stands in all lower 48 US states led to the suspicion that an exotic strain of

60 Phragmites might be responsible for this expansive spread (Meyerson et al. 2009). By 2007,

61 three genetic lineages of Phragmites were identified in North America based on genetic

62 sequence data: 1) P. australis subspecies americanus (native Phragmites hereafter), 2) $P$.

63 australis subspecies berlandieri (Gulf Coast Phragmites hereafter), and 3) P. australis haplotype

64 M (exotic Phragmites hereafter) (Saltonstall 2002; Saltonstall et al. 2004; Saltonstall and Hauber

65 2007; see Saltonstall 2016 for a thorough review of the many Phragmites haplotypes). Because 
66 of its ability to thrive in commonly disturbed environments and to outcompete native plants,

67 exotic Phragmites is considered one of the worst invaders of North American wetlands

68 (Meyerson et al. 2009), costing about \$4.6 million annually in control and eradication efforts

69 (Martin and Blossey 2013).

Understanding how native and exotic plants can impact ecosystems and microbially-

71 mediated nutrient cycling processes, especially denitrification, is necessary for properly

72 managing wetland ecosystems to help mitigate eutrophication. However, not much is known

73 about whether native and exotic Phragmites strains differ in their relationships to environmental

74 attributes, soil nutrients, denitrification rates, and their association with denitrifier microbes.

75 Because reliable identification of the different strains of Phragmites was not possible prior to the

76 molecular work of Saltonstall (2002), few studies have focused on ecological impacts of

77 different Phragmites strains. Our search of the literature identified several studies that examined

78 the effect of Phragmites on certain ecosystem attributes (Table 1). Of those studies, however,

79 only 11 addressed ecosystem impacts of genetically verified Phragmites strains (native versus

80 exotic; see bolded entries in Table 1), and more than half of those addressed differences in only

81 one variable (plant biomass), warranting further studies.

The available research addressing the impact of exotic Phragmites on ecosystem

83 properties suggests that its presence unequivocally contributes to an increase in plant biomass

84 and productivity because exotic Phragmites produces more shoots, has a higher growth rate,

85 generally grows taller, and produces more biomass than the native strain (Table 1; Lelong 2007;

86 Jodoin et al. 2008; Mozdzer et al. 2013). Although more Phragmites biomass usually correlates 
87 with higher soil organic matter (SOM) which could support denitrifying soil microbes and thus 88 enhance denitrification, some studies reported no difference in SOM or denitrification between 89 the exotic Phragmites strain and an area having vegetation other than exotic Phragmites (Table 90 1). More importantly, there are no studies to date that have compared SOM content and 91 denitrification rates between the exotic and native Phragmites strains (i.e., there are no bolded 92 citations on Table 1 under denitrification).

There are two contrasting scenarios that may explain the relationship between

$94 \quad$ Phragmites and soil nutrient concentrations (nitrate $\left(\mathrm{NO}_{3}\right)$, ammonium $\left(\mathrm{NH}_{4}\right)$, and phosphate $\left.95\left(\mathrm{PO}_{4}\right)\right)$. Studies have indicated that exotic Phragmites has a higher nutrient demand compared to 96 the native strain (Holdredge et al. 2010; Mozdzer and Zieman 2010; Mozdzer et al. 2013). In 97 addition, if the exotic strain has higher plant biomass than the native strain (e.g., Table 1) and if 98 nutrients are bound in those plant tissues (as reported in several studies for Biomass [N] in Table 99 1), then soil nutrient concentrations will be smaller under exotic Phragmites stands compared to 100 those under native stands. In contrast, soil nutrient concentrations may be larger under exotic 101 Phragmites stands if interactions with microbial communities enhance nutrient mineralization 102 rates. This latter pattern of increased soil nutrients has been documented in studies of other 103 invasive wetland plants such as exotic and hybrid Typha (Angeloni et al. 2006; Larkin et al. 104 2011; Geddes et al. 2014). However, our review of the literature shows only two studies (Price et 105 al. 2014; Yarwood et al. 2016) directly compared soil nutrient concentrations between exotic and 106 native Phragmites stands and their results showed variable results (i.e., larger, smaller, or equal 107 soil nutrient concentrations between exotic and native stands; Table 1). 
109 (soil temperature, water level, soil moisture, and soil pH), 2) soil nutrient concentrations (carbon 110 as soil organic matter, nitrate, ammonium, and phosphate), and 3) soil denitrification rates and 111 abundance of denitrifiers (as determined by nirS copy numbers) between stands dominated by 112 exotic Phragmites versus those dominated by native Phragmites. We hypothesized that sites 113 dominated by exotic Phragmites would have larger soil nutrient concentrations and higher rates 114 of denitrification than sites dominated by native Phragmites. Additionally, we predicted that the 115 abundance of denitrifying bacteria (as estimated by nirS copy numbers) would positively 116 correlate with nitrate concentration, because nitrate is used as the electron acceptor for 117 denitrification. We expected these latter relationships to be stronger in areas dominated by exotic 118 Phragmites than in areas dominated by the native strain.

119 In addition to comparing differences in ecosystem attributes between stands dominated 120 by exotic Phragmites versus those dominated by native Phragmites, we also examined 121 relationships between measured ecosystem attributes and Phragmites stem density of both strains 122 as well as water level using a regression approach. We acknowledge that invasive species are 123 likely to affect environmental attributes of the sites they invade (i.e., invasive species are the 124 cause of the measured changes), but they are also likely to invade areas that had certain 125 environmental conditions to begin with (i.e., the invasion is a consequence of pre-existing 126 conditions such as abiotic factors or nutrient concentrations). Specifically for Phragmites, 127 previous work has determined that several abiotic factors affect stem density, and hence these 128 abiotic gradients in combination with stem density may be responsible for the observed patterns 129 we report in our results. For example, salinity, nutrient availability, and hydrology/water level 
have all been shown to control Phragmites stem attributes such as density, height, diameter, and

131 biomass (e.g., Chambers, Meyereson and Saltonstall 1999; Meyerson et al. 2000a; Vretare et al. 132 2001; Chambers et al. 2003; Welch, Davis and Gates 2006; Saltonstall and Stevenson 2007; Eid 133 et al. 2010), where stem attributes correlate positively with increased fertility and negatively with 134 increased salinity (Engloner 2009). Responses of Phragmites stem attributes to hydrological 135 variation such as water depth or flooding frequency yielded more ambiguous results in previous 136 studies (Engloner 2009). Similarly to other correlational studies involving invasive species, 137 assigning causality can be difficult (e.g., Geddes et al. 2014; Price et al. 2014). Nevertheless, 138 correlational studies such as ours will enable the development of specific hypotheses regarding 139 the effects of exotic and native Phragmites on ecosystem properties that can be tested via 140 controlled manipulative experiments.

\section{Materials and Methods}

We measured environmental attributes, soil nutrient concentrations, denitrification, and 143 denitrifier abundance during the summer of 2011 in three sites dominated by native Phragmites 144 and in three sites dominated by exotic Phragmites; all stands had at least 95\% Phragmites cover. 145 Study sites were located in DuPage and Kane Counties in Illinois, and Lake County in Indiana 146 (Fig. 1). The exotic stands were located at Dick Young Forest Preserve, Burnidge Forest

147 Preserve, and Pratts Wayne Woods Forest Preserve, and the native stands were located at 148 Calumet Prairie (2 sites) and West Chicago Prairie (Fig. 1). Stands were identified as native or 149 exotic using genetic analysis (Price et al. 2014) following the methodology of Saltonstall et al. 150 (2004). 
152 27, 2011. All variables were measured at 5 randomly selected plots in each of the 6 sites, for a 153 total of 30 plots. Plots were spaced at 5-7 m intervals beginning 10 meters from the stand edge.

154 At each plot, we measured several variables in situ (see below) and we took a soil core ( 6-8 cm 155 in diameter, $\sim 10-14 \mathrm{~cm}$ deep) using a serrated knife to cut through the roots and two trowels to 156 extract the core, placed it in a Ziploc bag, and immediately stored it on ice. Soil cores were 157 placed in a refrigerator until analysis.

Phragmites Density and Environmental Attributes

Phragmites stem density was quantified by counting only new, green Phragmites aerial

161 stems using a $1 \mathrm{~m}$ x $0.5 \mathrm{~m}$ quadrat (total area sampled $=0.5 \mathrm{~m}^{2}$ ). Brown, senesced stems from 162 the previous season(s) were not included in the counts. Soil temperature was taken using a Fisher 163 Scientific Traceable Lollipop Waterproof/Shockproof Thermometer by inserting it $10 \mathrm{~cm}$ into 164 the soil. Depth of standing water was measured with a meter stick. Soil pH was determined in the 165 lab by mixing $15 \mathrm{~g}$ of soil with $30 \mathrm{~mL}$ DI water. The slurry was stirred and allowed to stand for 16630 minutes for $\mathrm{CO}_{2}$ equilibration after which $\mathrm{pH}$ was read with an ORION model $310 \mathrm{pH}$ meter 167 (Robertson et al. 1999). Soil moisture was calculated as the difference between dry and wet mass 168 of $10 \mathrm{~g}$ of wet soil sample that had been weighed and dried to constant weight in a drying oven at $169105^{\circ} \mathrm{C}$. 
172 from soil cores from each of the 30 plots. Soil cores were kept separate for all analyses. Roots, 173 twigs, and debris were removed from each soil core, and cores were then manually homogenized 174 and mixed within each individual Ziploc bag (i.e., cores were kept separate for analyses). 175 Subsamples from each soil core were then taken to determine soil nutrient content. All nutrient 176 concentrations were measured within 36 hours of sample collection.

SOM was measured as mass loss on ignition and quantified as ash-free dry mass 178 (AFDM). Ten grams of each wet soil sample were placed in an aluminum pan, weighed, and 179 dried to constant weight in a drying oven at $105^{\circ} \mathrm{C}$. Dry samples were then ashed in a muffle 180 furnace at $550^{\circ} \mathrm{C}$ for two hours to obtain AFDM values. SOM (\%) was calculated as a 181 percentage of soil dry mass (g) by dividing AFDM by soil dry mass and multiplying by 100 182 (APHA 2005).

Soil ammonium was measured using the phenol-hypochlorite method (Wetzel and Likens 184 1991), in KCl-extracted samples. Absorbance was recorded using a Shimadzu UV-Vis 185 spectrophotometer at $630 \mathrm{~nm}$ in $1 \mathrm{~cm}$ quartz cuvettes. Nitrate was measured in KCl-extracted 186 samples following the cadmium-reduction method on a Seal Analytical AQ2+ Discrete Auto-

187 analyzer. Soil orthophosphate was determined using the ascorbic acid method (Wetzel and 188 Likens 1991), using Troug's solution as the extractant (Mehlich 1953). Absorbance was recorded 189 using a Shimadzu UV-Vis spectrophotometer at $885 \mathrm{~nm}$ in $1 \mathrm{~cm}$ quartz cuvettes. 

enzyme activity) assay, based on the acetylene inhibition technique (Groffman et al. 1999). Although this technique has some caveats, it is a technique that is accessible in terms of cost, 194 allows large number of samples to be run simultaneously, and is still widely used (Groffman et 195 al. 2006). The technique involves the measurement of nitrous oxide concentration as a proxy for 196 potential denitrification. Therefore, comparative studies like this one that measure relative 197 denitrification potential rather than absolute denitrification fluxes are likely to be less affected by 198 the technique's caveats (e.g., Alldred et al. 2016).

200 reductase, the enzyme used by denitrifying bacteria in the last step of the denitrification pathway 201 to convert nitrous oxide to nitrogen gas, is inhibited by acetylene. Thus, this inhibition allows a 202 measurement of nitrous oxide concentration as a proxy for how much denitrification is possible 203 by the soil microbes under controlled lab conditions. The differences in nitrous oxide produced 204 were then used to compare the ability of soils to perform denitrification under native and exotic 205 stands of Phragmites.

206 Canning jars $(230 \mathrm{~mL})$ were fitted with butyl septa and $60 \mathrm{~mL}$ of soil were placed in each 207 jar along with water and an amendment that included glucose (as a carbon source; $120 \mathrm{mg}^{-1}$ ) 208 and nitrate $\left(140 \mathrm{mg} \mathrm{l}^{-1}\right)$ (Groffman et al. 1999) to form a slurry. Jars were flushed with helium for 209 five minutes to remove oxygen and then equilibrated to atmospheric pressure. $10 \mathrm{~mL}$ of 210 acetylene were then added to each jar and $4 \mathrm{~mL}$ gas samples were collected from the headspace 211 in jars at 30, 60, 90, and 180 minutes after acetylene addition and stored in gas-tight evacuated 
212 vials. Gas samples were quantified for nitrous oxide using a Shimadzu gas chromatograph (GC-

213 2014) equipped with an Electron Capture Detector (ECD) and a HayeSep Q stainless steel

214 column. Ultrapure nitrogen was the carrier gas, and the detector, oven, and injector temperatures

215 were set at $300{ }^{\circ} \mathrm{C}, 40^{\circ} \mathrm{C}$ and $60{ }^{\circ} \mathrm{C}$, respectively.

\section{Molecular Analyses of Soil Denitrifier Communities}

217 For the quantification of soil denitrifiers, we analyzed soil from 3 replicate cores chosen

218 randomly from the 5 replicate cores collected from each site, for a total of 18 samples (3 exotic

219 Phragmites sites x 3 plots each and 3 native Phragmites sites x 3 plots each). The abundance of

220 denitrifying bacteria in the sediments was assessed based on quantification of copy numbers of

221 nirS genes via real-time quantitative polymerase chain reaction (qPCR). The nirS gene encodes

222 the cytochrome-containing version of nitrite reductase (Braker et al. 1998), the enzyme that

223 catalyzes the reduction of nitrite to nitric oxide, which is the first committed step of

224 denitrification (Zumft 1997). The nirK gene, which encodes a functionally redundant version of

225 nitrite reductase (Braker et al. 1998), was not quantified. The nirS gene was chosen for this study

226 because previous work has shown that nirS-containing denitrifiers are abundant in wetlands, and

227 the copy number of nirS genes is commonly used as an indicator of the abundance of denitrifying

228 bacteria (e.g., Angeloni et al. 2006; Geddes et al. 2014).

Genomic DNA was isolated from each of the soil samples $(\sim 0.5 \mathrm{~g})$ with the UltraClean

230 Soil DNA Kit (MoBio Laboratories, Salana Beach, CA). Successful DNA isolation was

231 confirmed by agarose gel electrophoresis. The amount of DNA isolated from each sample was

232 determined with the Quant-iT DNA Assay Kit (Invitrogen, Carlsbad, CA). The nirS qPCR assay 
followed the approach described by Geets et al. (2007) except that the annealing temperature was

234 changed to $57^{\circ} \mathrm{C}$ and the extension temperature was changed to $72{ }^{\circ} \mathrm{C}$. All qPCR experiments

235 were run using an MJ Research DNA Engine Opticon1 thermal cycler equipped with Opticon

236 Monitor software version 3.1 (Biorad, Hercules, CA). Conditions for all qPCR reactions were as

237 follows: $12.5 \mu$ Q QuantiTect SYBR Green PCR Master Mix (Qiagen, Valencia, CA), $0.5 \mu \mathrm{M}$ final

238 concentration of each primer, $5 \mu$ template, and water were added to a final $25 \mu$ l volume. qPCR

239 was carried out using primers cd3AF (GTSAACGTSAAGGARACSGG) and R3cd

240 (GASTTCGGRTGSGTCTTGA), which produce a 425 base pair amplicon (Throbäck et al.

241 2004). All reactions were performed in low-profile $0.2 \mathrm{~mL}$ white strip tubes with optical ultra-

242 clear strip caps (Bio-Rad). Thermal cycling was as follows: initial denaturation at $95{ }^{\circ} \mathrm{C}$ for 10

243 min, 40 cycles of denaturation at $95^{\circ} \mathrm{C}$ for 1 min, primer annealing at $57^{\circ} \mathrm{C}$ for 1 min, extension

244 at $72{ }^{\circ} \mathrm{C}$ for $1 \mathrm{~min}$, hold at $78{ }^{\circ} \mathrm{C}$ for $1 \mathrm{sec}$, and plate read. Finally, a melting curve was run from

$24550-95{ }^{\circ} \mathrm{C}$ with a read every $1^{\circ} \mathrm{C}$ and a hold of $1 \mathrm{sec}$ between reads. Specificity of qPCR

246 reactions was confirmed by melting curve analysis and agarose gel electrophoresis.

The standard used for qPCR reactions was a cloned nirS gene from Paracoccus

denitrificans (ATCC 13543). P. denitrificans was grown according to ATCC guidelines and

249 DNA was extracted using the UltraClean Microbial Isolation Kit (MoBio). nirS genes were

250 amplified from this DNA using the $\mathrm{cd} 3 \mathrm{aF}$ and R3cd primers and the PCR conditions described

251 by Throbäck et al. (2004). PCR amplicons were cloned with the TOPO-TA cloning kit

252 (Invitrogen) using vector pCR4 and transformed into chemically competent Escherichia coli.

253 Transformed E. coli were grown overnight on LB agar plates containing $50 \mu \mathrm{g} / \mathrm{mL}$

254 kanamycin. Several randomly selected colonies were transferred to LB broth containing 50 
$\mu \mathrm{g} / \mathrm{mL}$ kanamycin, grown overnight at $37^{\circ} \mathrm{C}$, and PCR-screened for the presence of inserts of 256 appropriate size using M13F and M13R primers. Plasmids containing the appropriately sized 257 inserts were isolated using PureLink Quick Plasmid Miniprep Kit (Invitrogen). Plasmids were 258 digested with EcoRI (New England BioLabs) according to the manufacturer's instructions and 259 the digestion reaction was run on an agarose gel. The fragment containing nirS was cut out from 260 the gel and purified using QIAquick Gel Extraction Kit (Qiagen). The concentration of this nirS261 containing fragment was determined by Quant-iT DNA Assay Kit (Invitrogen). Standard curves

262 for qPCR reactions were generated using a 10-fold dilution series ranging from 1.37 x $10^{6}$ to 137 263 copies of nirS. nirS copy numbers were normalized based on grams of soil.

\section{Data Analysis}

265 We compared all measured variables between sites with native Phragmites strains and 266 those with exotic strains using t-tests $(n=3)$. Additionally, to address the relationship between 267 density of Phragmites and the measured environmental attributes, soil nutrient concentrations, 268 denitrification, and soil denitrifier abundance (nirS copy numbers), we conducted separate 269 regression analyses using the number of Phragmites stems per square meter or water level as the 270 independent variable, combining both strains together, as well as separately for each strain (i.e.,

271 exotic and native). All dependent variables were log-transformed to conform to assumptions of 272 homoscedasticity. Data analyses were performed using Systat v. 11 (Systat Software, Inc., San 273 Jose, CA). Alpha $\leq 0.05$ was used to evaluate significance.

\section{$274 \quad$ RESULTS}


276 the measured variables between the exotic Phragmites and native Phragmites sites, with the

277 exception of $\mathrm{pH}$. Soils associated with the exotic strain had higher soil $\mathrm{pH}(7.41)$ than that

278 associated with the native strain $(7.08)(\mathrm{P}=0.048)$. There was also no significant difference in

279 Phragmites stem density between exotic and native Phragmites sites $(\mathrm{P}=0.787)$. Exotic

280 Phragmites sites had a stem density mean of 36.26 stems $\mathrm{m}^{-2}( \pm 11.8 \mathrm{SD})$ whereas the native

281 sites had a mean of 41.13 stems $\mathrm{m}^{-2}( \pm 27.41 \mathrm{SD})$. Although not significant, the sites dominated

282 by native Phragmites had slightly higher stem numbers than sites dominated by their exotic

283 counterpart, a result that contradicted our expectations. Additionally, there was large variability

284 in Phragmites stem densities across sites, and this variability was much greater in native

285 Phragmites sites (range: 8.6-60.4 stems $\mathrm{m}^{-2}$ ) than in the exotic Phragmites sites (range: $28-40.8$

286 stems $\mathrm{m}^{-2}$ ). Similarly to stem density, surface water levels had greater variability in native

287 Phragmites sites (range: 0-5 cm, SD = 1.94) than in exotic Phragmites sites (range: 0-1.5 cm, SD

$288=0.39)$.

Linear regression analysis using stem density of exotic Phragmites as the explanatory variable revealed no significant correlations for any of the measured variables (nitrate, ammonia,

291 phosphate, SOM, soil moisture, denitrification potential, soil temperature, soil $\mathrm{pH}$, or water 292 level) (Fig. 2). Denitrifier abundance was also not significantly correlated with exotic 293 Phragmites stem density $(\mathrm{P}=0.448$; data not shown $)$.

In contrast, native Phragmites stem density showed significant correlations with all 295 measured variables except for nitrate, soil moisture, and $\mathrm{pH}$ (Fig. 3), as well as for denitrifier 
296 abundance $(\mathrm{P}=0.134$; data not shown). Specifically, we found positive relationships between

297 Phragmites stem density and ammonium $(\mathrm{P}<0.001), \mathrm{SOM}(\mathrm{P}=0.012)$, phosphate $(\mathrm{P}=0.047)$,

298 and denitrification potential rates $(\mathrm{P}=0.003)$, and negative relationships with temperature $(\mathrm{P}=$

299 0.043) and water level (P < 0.001) (Fig. 3). Lastly, linear regression analysis using stem density

300 of exotic and native Phragmites combined as the explanatory variable to address if stem density

301 per se, irrespective of strain, was responsible for the observed patterns revealed significant

302 correlations that matched those of the native Phragmites stem density alone, suggesting the

303 native strain was the one that had the greatest influence over the significant results (data not

304 shown).

For soils under the native Phragmites strain, we found that nirS copy numbers were

306 significantly correlated with soil nitrate concentrations and denitrification potential rates.

307 Specifically, there was a positive correlation between nirS copy numbers and nitrate

308 concentrations $\left(\mathrm{P}=0.002, \mathrm{R}^{2}=0.759\right.$, Fig. $\left.4 \mathrm{~A}\right)$ as well as for denitrification rates $\left(\mathrm{P}=0.014, \mathrm{R}^{2}\right.$

$309=0.604$, Fig. 4B). These relationships were not significant for soils under the exotic strain.

When water level in sites with native Phragmites was compared with the measured

311 variables, we found significant negative correlations with native Phragmites stem density $(\mathrm{P}<$

312 0.001), nitrate $(\mathrm{P}=0.049)$, ammonium $(\mathrm{P}=0.010)$, phosphate $(\mathrm{P}=0.018), \mathrm{SOM}(\mathrm{P}=0.007)$,

313 and denitrification $(\mathrm{P}<0.001)$, and a positive correlation with soil temperature $(\mathrm{P}=0.004)$ (Fig.

314 5). However, we found no correlations between water level from sites with exotic Phragmites

315 and any of the measured variables (data not shown).

\section{DISCUSSION}


318 states (Meyerson et al. 2009), yet little is known about whether sites that have experienced this

319 invasion versus sites with a native Phragmites strain possess different relationships to ecosystem

320 properties (Meyerson et al. 2009). Our study addressed information gaps concerning differences

321 in environmental attributes, soil nutrient concentrations, and denitrification in soils of native and

322 exotic Phragmites stands. Contrary to previous studies and to our own expectations, this study

323 revealed no differences in measured variables when comparing native versus exotic sites, and

324 that native Phragmites exhibited stronger correlations with the measured parameters than exotic

325 Phragmites when stem density was considered.

In addition, water level showed strong correlations with many measured parameters in

327 native Phragmites sites, including native Phragmites stem density, suggesting this abiotic driver

328 may have mediated the responses we observed with stem density. However, we acknowledge

329 that our measurements of water level were limited to single time points and to surface water.

330 More sophisticated techniques such as wells, piezometers, and/or graduated staff gauges, as well

331 as incorporation of groundwater level estimates, would have provided more detailed information

332 on the hydrology of these sites. Furthermore, multiple measurements over an extended period of

333 time (hydrographs or time series) prior to our sampling date would have provided additional

334 insight into the potential effects of hydrology on the biotic and abiotic variables measured in our

335 study. Our surface water level measurement represents one time point that could potentially

336 reflect conditions of only a couple of days before sampling, as opposed to more long-term water

337 dynamics. Therefore, although several variables in our study show strong correlations with water

338 level, we recognize the shortcomings of our measurements. Ultimately, our results may reflect 
differences in water level or other abiotic gradients that themselves affect and control stem density. Yet it is possible that the reverse is true: stem density may lead to marked differences in plant evapotranspiration rates and accumulation of plant litter, both of which can affect surface water levels. We thus discuss our findings providing possible alternative explanations where appropriate. Despite this caveat, we contend that these results provide novel information regarding the effects of the native Phragmites strain at high stem densities, a seemingly rare occurrence given the reported values of native Phragmites stem density in the literature (see below). Teasing apart if the invasive species are the cause or the consequence of the change in environmental attributes can ultimately be achieved through controlled experimentation, and we strongly argue for this experimental approach for a more mechanistic understanding of the effects of exotic and native Phragmites on ecosystems.

Previous research suggests that exotic Phragmites develops more dense stands than native Phragmites (e.g., League et al. 2006; Hansen et al. 2007; Saltonstall and Stevenson 2007; Meyerson et al. 2009; Price et al. 2014). We found Phragmites stem density was highly variable, especially for the native strain, and that water levels in the native Phragmites sites negatively correlated with stem density. Our small sample size of selected sites $(n=3)$ may have affected our ability to detect significant differences between Phragmites strains. However, similar to our findings, a few other studies have also indicated that native Phragmites stands can exhibit high stem densities (Lynch and Saltonstall 2002; Meyerson et al. 2009; Saltonstall et al. 2010). It is likely that the native strain may indeed have important ecosystem effects once a threshold stem density (or biomass) is reached. A wide range of native Phragmites densities have been reported in the literature: 22.3 stems $\mathrm{m}^{-2}$ (Price et al. 2014), 37.3 stems $\mathrm{m}^{-2}$ (Mozdzer and Zieman 2010), 
361 and 55 stems $\mathrm{m}^{-2}$ (Rodríguez and Brisson 2015). In comparison, we found average native stand 362 stem densities of 41.13 stems $\mathrm{m}^{-2}$; the maximum density in native stands was $82 \mathrm{stems}^{-2}$, 363 whereas in exotic stands the maximum was 54 stems $\mathrm{m}^{-2}$.

364 We found negative correlations between native Phragmites stem density and water level 365 and soil temperature. High native Phragmites stem densities may have correlated with low water 366 levels because native Phragmites is presumably less tolerant of standing water than exotic 367 Phragmites (Meyerson et al. 2009; Price et al. 2014) and therefore selectively invades areas with 368 lower water levels. Alternatively, native Phragmites could be responsible for more efficient 369 water uptake than its exotic counterpart and/or enhanced evapotranspiration rates, keeping water 370 levels low. The negative correlation between native Phragmites stem density and soil 371 temperature was likely due to the height and leaf surface area that Phragmites can achieve 372 (Meyerson et al. 2009; Saltonstall et al. 2010; Mozdzer and Zieman 2010; Hirtreiter and Potts 373 2012; Price et al. 2014). In denser native Phragmites stands, shading of the understory could 374 have resulted in lower soil temperatures. A similar phenomenon was observed in exotic 375 Phragmites stands in other studies, where standing water temperatures decreased due to the 376 shading from the plant canopy (Rogalski and Skelley 2012) or from accumulated litter 377 (Holdredge and Bertness 2011). However, we found a positive correlation between standing 378 water levels and soil temperature (Fig. 5). Although we observed no significant correlations 379 between native or exotic Phragmites stem density or water level and $\mathrm{pH}$, the significant 380 difference we found in $\mathrm{pH}$ when comparing native and exotic stands may imply that 1) there may 381 be a systematic preference of the exotic strain for alkaline soils, 2) the exotic strain has not been 
established long enough to acidify the soil to the extent of the native strain, or 3) that some other

383 disturbance in the sites with the exotic strain led to systematic increases in $\mathrm{pH}$.

Native Phragmites density also correlated positively with soil organic matter. Given

Phragmites' ability to produce high amounts of biomass, dead plant matter can accumulate rapidly, decreasing light availability (Holdredge and Bertness 2011; Hirtreiter and Potts 2012) and eventually decomposing into soil organic matter. As expected, SOM negatively correlated with water level, as decomposition of organic matter depends on an oxic environment. It has

389 been documented that Phragmites accumulates so much SOM that it tends to terrestrialize the 390 wetland ecosystems that it invades (Chambers et al. 1999; Windham 2001; Rooth et al. 2003; 391 Meyerson et al. 2009), even changing habitat characteristics for fauna (Derr 2008; Meyerson et 392 al. 2010). This trend of increased SOM has also been documented in other exotic species such as 393 Typha x glauca (Angeloni et al. 2006; Larkin et al. 2011; Mitchell et al. 2011; Geddes et al. 394 2014). The positive correlation between increasing SOM and increasing native Phragmites stem 395 density found in this study corroborates these latter claims and points to effects of the native 396 strain being similar to or even greater than those of the exotic strain, at least in our study sites.

397 Because SOM has not been reported to be an important determinant of stem density in previous 398 research (e.g., Engloner 2009), we believe native Phragmites density was likely a driver for 399 SOM production.

Our finding that native Phragmites stem density had a positive correlation with soil 401 ammonium and phosphate concentrations may provide support for the claim that native plant 402 strains can have the ability to modify nutrient concentrations similarly to invasive exotic 
403

404

405

406

407

408

409

410

411

counterparts. A similar finding was documented by Price et al. (2014) for soil ammonium and nitrate, but not for phosphate. However, due to the correlational nature of this study, it is also likely that we observed higher native Phragmites stem density in areas where soil ammonium and phosphate concentrations were larger as these are important nutrients that limit plant growth and control stem density (e.g., Meyerson et al. 2000a; Welch, Davis, and Gates 2006; Saltonstall and Stevenson 2007; Engloner 2009; Eid et al. 2010). In contrast, water levels negatively correlated with all measured nutrients: nitrate, ammonium, and phosphate (Fig. 5), suggesting that increased water levels may have slowed microbial decomposition of organic matter and mineralization of inorganic nutrients due to decreased oxygen availability.

Although the exotic Phragmites strain has been considered a useful plant in remediation studies due to its ability to remove excess nutrients and improve water quality (e.g., Araki et al. 2005; Ruiz-Rueda et al. 2009; Rodríguez and Brisson 2015), results from our study suggest that it was the native strain that exhibited a positive correlation between Phragmites stem density and denitrification (Fig. 3). Rodríguez and Brisson's study (2015) and our study are the only two examples that we know of that show significant effects of the native strain on nutrient removal phosphate in their study; nitrate through denitrification in ours- when compared to the exotic one, perhaps as a result of native stand stem densities being on the highest end of those reported in the literature. Yet it is important to exercise caution when interpreting these data as another explanation may involve the reverse pattern: if there are higher stem densities in areas with higher levels of soil nitrate, then denitrification rates may be higher due to higher soil nitrate concentrations, and not necessarily due to the higher native stem densities. However, we found no relationship between soil nitrate and increasing native stem density (Fig. 3), weakening the 
425 support for this latter explanation. Our study also showed that denitrification rates were

426 negatively correlated with water level (Fig. 5) and thus we contend that water level may have

427 been a driver of denitrification rates alone or in combination with stem density. Lastly, we found

428 a positive correlation between soil nitrate under the native strain with the number of copies of the 429 nirS gene, an indicator of denitrifier abundance (Fig. 4A). In turn, copies of the nirS gene

430 positively correlated with denitrification rates (Fig. 4B). Our study is novel in that the microbial 431 composition difference between these strains can shed light on ecosystem functioning. However, 432 more studies are needed that compare the microbial communities under native versus exotic 433 strains (but see Yarwood et al. 2016).

If one of the goals of preserving wetland integrity while maximizing water purification 435 functions is to maintain or increase denitrification rates, our study suggests lowering water levels 436 and/or preserving the native strain when in highly dense stands might be a viable option.

437 Similarly, Rodríguez and Brisson (2015) have suggested utilizing the native strain of Phragmites

438 for phosphate removal. However, management of wetlands that have both native and exotic 439 strains poses problems because identification of strains is difficult morphologically and usually 440 relies on molecular analyses that are not widely accessible to managers. Further experimental 441 tests are required before research can effectively inform management practices regarding this 442 species.

\section{CONCLUSION}

Our research showed that although exotic Phragmites australis has been extensively

445 documented as an aggressive wetland invader, gradients in native $P$. australis stem density and 
water level exhibited significant correlations with environmental attributes, soil nutrient

447 concentrations, and denitrification in our study sites, whereas the exotic strain did not. The fact

448 that we did not detect any correlations between exotic Phragmites stem density and measured

449 variables but did so for the native strain implies that 1) there is something inherently different

450 about the two strains, with the native strain being the cause of the observed correlations, 2) the

451 native strain selectively invaded sites that had certain pre-existing environmental attributes that

452 controlled stem density and, as a consequence, it showed correlations with those environmental

453 attributes, and/or 3) water levels may drive the observed patterns alone or in combination with

454 other factors, and can thus mediate the responses observed. Further experimental work that

455 compares genetically identified native and exotic Phragmites as well as controls for pre-existing

456 environmental attributes to avoid confounding interpretations are needed to provide further

457 insight into whether the two strains have different ecosystem impacts. Additionally, given the

458 high variability likely found in many variables associated with Phragmites stands, studies with

459 high stand replication covering a broader geographic scope are warranted.

461 ACKNOWLEDGMENTS

462 We would like to thank our collaborators at the Chicago Botanic Garden, Dan Larkin, Jeremie

463 Fant, Amy Price, and Paul Hartzog, for genetically identifying Phragmites and allowing us to

464 conduct nitrate analyses. In addition, we would like to acknowledge the support of Kane,

465 DuPage, and Lake (IN) County Forest Preserves, and IL Nature Preserves Commission for

466 permits and access to sites. We thank John Kasmer and Joel Olfelt for their editorial 
467 contributions to the manuscript, and Lynnette Murphy for creating the map of sampling sites. 468 Financial support for this study was provided by a Research Starter Grant to P.G. from the 469 National Science Foundation (DEB 1034855). Work by S.I. was supported by a Loyola 470 University Chicago WISER Fellowship.

471

472 REFERENCES

473

474 Alldred M, Baines SB, Findlay, S (2016) Effects of invasive-plant management on nitrogen 475 removal services in freshwater marshes. PLoS One 11(2):e0149813;

476 doi:10.1371/journal.pone.0149813

477

478 Angeloni NL, Jankowski KJ, Tuchman NC, Kelly JJ (2006) Effects of an invasive cattail species

479 (Typha $\mathrm{x}$ glauca) on sediment nitrogen and microbial community composition in a freshwater 480 wetland. FEMS Microbiology Letters 263:86-92

481

482 APHA (2005) Standard Methods for the Examination of Water and Wastewater, $21^{\text {st }}$ edn. 483 American Public Health Association, Washington, DC

484

485 Araki R, Mori M, Mori M, Hasegawa H (2005) Genetic differences in nitrate uptake in two 486 clones of the common reed, Phragmites australis. Breeding Science 55:297-302 
488 Bastviken SK, Eriksson PG, Premrov A, Tonderski K (2005) Potential denitrification in wetland 489 sediments with different plant species detritus. Ecological Engineering 25:183-190

490

491 Braker G, Fesefeldt A, Witzel KP (1998) Development of PCR primer systems for amplification

492 of nitrite reductase genes (nirK and nirS) to detect denitrifying bacteria in environmental

493 samples. Applied and Environmental Microbiology 64: 3769-3775

494

495 Carey CJ, Blankinship JC, Eviner VT, Malmstrom CM, Hart SC (2017) Invasive plants decrease 496 microbial capacity to nitrify and denitrify compared to native California grassland communities.

497 Biological Invasions DOI 10.1007/s10530-017-1497-y :1-17

498

499 Chambers RM, Meyerson LA, Saltonstall K (1999) Expansion of Phragmites australis into tidal 500 wetlands of North America. Aquatic Botany 64:261-273

501

502 Chambers RM, Osgood DT, Bart DJ, Montalto F (2003) Phragmites australis invasion and 503 expansion in tidal wetlands: Interactions among salinity, sulfide, and hydrology. Estuaries $504 \quad 26(2 B): 398-406$

505

506 Dassonville N, Guillaumaud N, Piola F, Meerts P, Poly F (2011) Niche construction by the 507 invasive Asian knotweeds (species complex Fallopia): Impact on activity, abundance 508 and community structure of denitrifiers and nitrifiers. Biological Invasions 13:1115-1133 509 
510 Derr JF (2008) Common reed (Phragmites australis) response to mowing and herbicide

511 application. Invasive Plant Science and Management 1:12-26

512

513 Duke S, Francoeur SN, Judd KE (2015) Effects of Phragmites australis invasion on carbon

514 dynamics in a freshwater marsh. Wetlands 35(2): 311-321

515

516 Ehrenfeld JG (2000) Evaluating wetlands within an urban context. Ecological Engineering

$517 \quad 15: 253-265$

518

519 Ehrenfeld JG (2003) Effects of exotic plant invasions on soil nutrient cycling processes.

520 Ecosystems 6:503-523

521

522 Eid ME, Shaltout KH, Al-Sodany YM, Jensen K (2010) Effects of abiotic conditions on

523 Phragmites australis along geographic gradients in Lake Burullus, Egypt. Aquatic Botany

$52492(2): 86-92$

525

526 Engloner AI (2009) Structure, growth dynamics and biomass of reed (Phragmites australis) - A

527 review. Flora 204:331-346

528

529 Evans RD, Rimer R, Sperry L, Belnap J (2001) Exotic plant invasion alters nitrogen dynamics in 530 an arid grassland. Ecological Applications 11(5):1301-1310

531 
532 Galatowitsch SM, Anderson NO, Ascher PO (1999) Invasiveness in wetland plants in temperate 533 North America. Wetlands 19:733-755

534

535 Geddes P, Grancharova T, Kelly JJ, Treering D, Tuchman NC (2014) Effects of invasive Typha $536 \times$ glauca on wetland nutrient pools, denitrification, and bacterial communities are influenced by 537 time since invasion. Aquatic Ecology 48:247-258

539 Geets J, de Cooman M, Wittebolle L, Heylen K, Vanparys B, De Vos P, Verstraete W, Boon N 540 (2007) Real-time PCR assay for the simultaneous quantification of nitrifying and denitrifying 541 bacteria in activated sludge. Applied Microbiology and Biotechnology 75(1):211-21

543 Groffman, PM, Altabet MA, Bohlke JK, Butterbach-Bahl K, David MB, Firestone MK, Giblin 544 AE, Kana TM, Nielsen LP, Voytek MA (2006) Methods for measuring denitrification: Diverse 545 approaches to a difficult problem. Ecological Applications 16(6):2091-2122 546

547 Groffman PM, Holland EA, Myrold DD, Robertson GP, Zou X (1999) Denitrification. In: 548 Robertson GP, Coleman DC, Bledsoe CS, Sollins P (eds) Standard soil methods for long-term 549 ecological research. Oxford University Press, New York, pp 272-288 550

551 Hansen DL, Lambertini C, Jampeetong A, Brix H (2007) Clone-specific differences in 552 Phragmites australis: Effects of ploidy level and geographic origin. Aquatic Botany 86:269-279 553 
554 Hirtreiter JN, Potts DL (2012) Canopy structure, photosynthetic capacity and nitrogen

555 distribution in adjacent mixed and monospecific stands of Phragmites australis and Typha

$556 \quad$ latifolia. Plant Ecology 213:821-829

557

558 Holdredge C, Bertness MD (2011) Litter legacy increases the competitive advantage of invasive 559 Phragmites australis in New England wetlands. Biological Invasions 13:423-433

560

561 Holdredge C, Bertness MD, von Wettberg E, Silliman BR (2010) Nutrient enrichment enhances

562 hidden differences in phenotype to drive a cryptic plant invasion. Oikos 119:1776-1784

563

564 Jodoin Y, Lavoie C, Villeneuve P, Theriault M, Beaulieu J, Belzile F (2008) Highways as

565 corridors and habitats for the invasive common reed Phragmites australis in Quebec, Canada.

566 Journal of Applied Ecology 45:459-466

567

568 Kulmatiski A, Beard KH, Meyerson LA, Gibson JR, Mock KE (2010) Nonnative Phragmites

569 australis invasion into Utah wetlands. Western North American Naturalist 70(4):541-552

570

571 Larkin D, Freyman MJ, Lishawa SC, Geddes P, Tuchman NC (2011) Mechanisms of dominance

572 by the invasive cattail Typha x glauca. Biological Invasions 14:827-838

573 
574 League MT, Colbert EP, Seliskar DM, Gallagher JL (2006) Rhizome growth dynamics of native 575 and exotic haplotypes of Phragmites australis (common reed). Estuaries and Coasts 29(2):269$576 \quad 276$

577

578 Lelong B, Lavoie C, Jodoin Y, Belzile F (2007) Expansion pathways of the exotic common reed 579 (Phragmites australis): A historical and genetic analysis. Diversity and Distributions 13:430-437 580

581 Liao C, Peng R, Luo Y, Zhou X, Wu X, Fang C, Chen J, Li B (2008) Altered ecosystem carbon 582 and nitrogen cycles by plant invasion: a meta-analysis. New Phytologist 177:706-714 583

584 Lishawa, SC, Jankowski KJ, Geddes P, Larkin DJ, Monks AM, Tuchman NC (2014)

585 Denitrification in a Laurentian Great Lakes coastal wetland invaded by hybrid cattail (Typha $\times$ 586 glauca). Aquatic Sciences 76:483-495

587

588 Lynch EA, Saltonstall K (2002) Paleoecological and genetic analyses provide evidence for 589 recent colonization of native Phragmites australis populations in a Lake Superior wetland. 590 Wetlands 22(4):637-646

591

592 Martin LJ, Blossey B (2013) The runaway weed: costs and failures of Phragmites australis 593 management in the USA. Estuaries and Coasts 36(3):626-632 
595

596

597

598

599

600

601

602

603

604

605

606

607

608

609

610

611

612

613 Mitchell ME, Lishawa SC, Geddes P, Larkin DJ, Treering D, Tuchman NC (2011) Time-

614 dependent impacts of cattail invasion in a Great Lakes coastal wetland complex. Wetlands

$615 \quad 31: 1143-1149$

616

Mehlich A (1953) Determination of P, Ca, Mg, K, Na, and NH4. Soil Testing Div. Publ. 1-53. North Carolina Dept. Agriculture, Raleigh, NC

Meyerson LA, Saltonstall K, Chambers RM (2009) Phragmites australis in eastern North America: A historical and ecological perspective. In: Silliman BR, Grosholz E, Bertness MD (eds) Salt marshes under global siege. University of California Press, California, pp 57-82

Meyerson LA, Saltonstall K, Windham L, Kiviat E, Findlay S (2000a) A comparison of Phragmites australis in freshwater and brackish marsh environments in North America. Wetlands Ecology and Management 8:89-103

Meyerson LA, Viola DA, Brown RN (2010) Hybridization of invasive Phragmites australis with a native subspecies in North America. Biological Invasions 12:103-111

Meyerson LA, Vogt KA, Chambers RM (2000b) Linking the success of Phragmites to the alteration of ecosystem nutrient cycles. In: Weinstein MP, Kreeger DA (eds) Concepts and controversies in tidal marsh ecology. Kluwer Academic Publishers, Norwell, MA pp 827-844 
617 Mozdzer TJ, Brisson J, Hazelton ELG (2013) Physiological ecology and functional traits of 618 North American native and Eurasian introduced Phragmites australis lineages. AoB PLANTS 619 5:plt048. doi: 10.1093/aobpla/plt048

620

621 Mozdzer TJ, Langley JA, Mueller P, Megonigal JP (2016) Deep rooting and global change

622 facilitate spread of invasive grass. Biological Invasions 18:2619-2631

623

624 Mozdzer TJ, Megonigal JP (2012) Jack-and-master trait responses to elevated CO2 and N:

625 A comparison of native and introduced Phragmites australis. PLoS ONE 7(10): e42794.

626 doi:10.1371/journal.pone.0042794

627

628 Mozdzer TJ, Zieman JC (2010) Ecophysiological differences between genetic lineages facilitate

629 the invasion of non-native Phragmites australis in North American Atlantic coast wetlands.

630 Journal of Ecology 98:451-458

631

632 Nijburg JW, Laanbroek HJ (1997) The fate of ${ }^{15} \mathrm{~N}$-Nitrate in healthy and declining Phragmites 633 australis stands. Microbial Ecology 34:254-262

634

635 Packett CR, Chambers RM (2006) Distribution and nutrient status of haplotypes of the marsh 636 grass Phragmites australis along the Rappahannock River in Virginia. Estuaries and Coasts $637 \quad 29: 1222-1225$

638 
639 Price AL, Fant JB, Larkin DJ (2014) Ecology of native vs. introduced Phragmites australis

640 (common reed) in Chicago-area wetlands. Wetlands 34:369-377

641

642 Robertson GP, Coleman DC, Bledsoe CS, Sollins P (1999) Standard soil methods for long-term

643 ecological research. Oxford University Press, New York

644

645 Rodríguez M, Brisson J (2015) Pollutant removal efficiency of native versus exotic common 646 reed (Phragmites australis) in North American treatment wetlands. Ecological Engineering $647 \quad 74: 364-370$

648

649 Rogalski MA, Skelly DK (2012) Positive effects of nonnative invasive Phragmites australis on 650 larval bullfrogs. PLoS ONE 7(8):e44420. doi:10.1371/journal.pone.0044420

651

652 Rooth JE, Stevenson JC, Cornwell JC (2003) Increased sediment accretion rates following 653 invasion by Phragmites australis: The role of litter. Estuaries 26(2B):475-483

654

655 Rothman E, Bouchard V (2007) Regulation of carbon processes by macrophyte species in a 656 Great Lakes coastal wetland. Wetlands 27(4):1134-1143

657

658 Ruiz-Rueda O, Hallin S, Baneras L (2009) Structure and function of denitrifying bacterial 659 communities in relation to the plant species in a constructed wetland. FEMS Microbiology 660 Ecology 67(2):308-319 
662 Saltonstall K (2002) Cryptic invasion by a non-native genotype of the common reed, Phragmites 663 australis, into North America. Proceedings of the National Academy of Sciences USA 99:2445-

6642449

665

666 Saltonstall K (2016) The naming of Phragmites haplotypes. Biological Invasions 18:2433-2441

667

668 Saltonstall K, Hauber D (2007) Notes on Phragmites australis (Poaceae: Arundinoideae) in 669 North America Journal of Botanical Research Institute of Texas 1:385-388

670

671 Saltonstall K, Lambert A, Meyerson LA (2010) Genetics and reproduction of common and giant 672 reed. Invasive Plant Science and Management 3:495-505

673

674 Saltonstall K, Peterson PM, Soreng RJ (2004) Recognition of Phragmites australis subsp.

675 americanus (Poaceae: Arundinoideae) in North America: Evidence from morphological and 676 genetic analysis. SIDA 21(2):683-692

677

678 Saltonstall K, Stevenson JC (2007) The effect of nutrients on seedling growth of native and 679 introduced Phragmites australis. Aquatic Botany 86:331-336 
681 Theuerkauf SJ, Puckett BJ, Theuerkauf KW, Theuerkauf EJ, Eggleston DB (2017) Density-

682 dependent role of an invasive marsh grass, Phragmites australis, on ecosystem service provision.

683 PLoS One 12(2): e0173007. doi: 10.1371/journal.pone.0173007

684

685 Throbäck IN, Enwall K, Jarvis S, Hallin S (2004) Reassessing PCR primers targeting nirS, nirK

686 and nos $Z$ genes for community surveys of denitrifying bacteria with DGGE. FEMS

687 Microbiology Ecology 49:401-417

688

689 Tulbure MG, Johnston KA (2010) Environmental conditions promoting non-native Phragmites

690 australis expansion in Great Lakes Coastal Wetlands. Wetlands 30:577-587

691

692 Vretare V, Weisner SEB, Strand JA, Granéli W (2001) Phenotypic plasticity in Phragmites

693 australis as a functional response to water depth. Aquatic Botany 69:127-145

694

695 Wang WQ, Sardans J, Wang C, Zeng CS, Tong C, Asensio D, Peñuelas J (2015) Ecological

696 stoichiometry of C, N, and P of invasive Phragmites australis and native Cyperus malaccensis

697 species in the Minjiang River tidal estuarine wetlands of China. Plant Ecology 216(6): 809-822

698

699 Welch BA, Davis CB, Gates RJ (2006) Dominant environmental factors in wetland plant 700 communities invaded by Phragmites australis in East Harbor, Ohio, USA. Wetlands Ecology

701 and Management 14(6):511-525

702 
705 Windham L (2001) Comparison of biomass production and decomposition between Phragmites 706 australis (common reed) and Spartina patens (salt hay grass) in brackish tidal marshes of New 707 Jersey, USA. Wetlands 21(2):179-188

708

709 Windham L, Ehrenfeld JG (2003) Net impact of a plant invasion on nitrogen-cycling processes 710 within a brackish tidal marsh. Ecological Applications 13(4):883-897

711

712 Windham L, Lathrop RG (1999) Effects of Phragmites australis (common reed) invasion on 713 aboveground biomass and soil properties in brackish tidal marsh of the Mullica River, New 714 Jersey. Estuaries 22(4):927-935

715

716 Windham L, Meyerson LA (2003) Effects of common reed (Phragmites australis) expansions on 717 nitrogen dynamics of tidal marshes of the Northern US. Estuaries 26(2B):452-464

718

719 Yarwood SA, Baldwin AH, Gonzalez Mateu M, Buyer JS (2016) Archaeal rhizosphere 720 communities differ between the native and invasive lineages of the wetland plant Phragmites 721 australis (common reed) in a Chesapeake Bay subestuary. Biological Invasions 18:2717-2728 722

723 Zedler JB (2003) Wetlands at your service: Reducing impacts of agriculture at the watershed 724 scale. Frontiers in Ecology and the Environment 1(2):65-72 
726 Zumft WG (1997) Cell biology and molecular basis of denitrification. Microbiology and

727 Molecular Biology Reviews 61:533-536

728

729 List of Figures

730 Figure 1. Map of sampling sites. GPS coordinates for the 6 sampling sites: Lake County, IN: N 73141 35.400'- W 087 14.838' and N 41 35.428'- W 087 14.9'; DuPage County, IL: N 41 53.499'732 W 088 13.412' and N 41 55.632'- W 088 13.208'; and Kane County, IL: N 42 04.263'- W 088 $73322.210^{\prime}$ and N $4150.212^{\prime}-\mathrm{W} 088$ 22.354'.

734 Figure 2. Relationships between stem density of exotic Phragmites to environmental attributes, 735 soil nutrients, and denitrification.

736 Figure 3. Relationships between stem density of native Phragmites to environmental attributes, 737 soil nutrients, and denitrification.

738 Figure 4. Relationships between soil $\mathrm{NO}_{3}$ and $n i r S$ copies (A) and between $n i r S$ copies and 739 denitrification (B) in sites containing native Phragmites.

740 Figure 5. Relationships between water level in native Phragmites sites to stem density, 741 environmental attributes, soil nutrients, and denitrification. 
Table 1. Summary of studies that examine the effect of exotic P. australis (haplotype $\mathrm{M}$ ) on several

744 ecosystem attributes. A plus (+) indicates that there was an increase in the ecosystem attribute for a site

745 with exotic Phragmites (putative; not necessarily genetically identified) when compared to a site without

746 exotic Phragmites (i.e., with vegetation other than exotic Phragmites), a minus (-) indicates a decrease in

747 the ecosystem attribute, and an equal sign (=) indicates there was no difference between the two sites.

748 Bolded entries designate studies that compared genetically identified Phragmites. A plus (+) indicates

749 that there was an increase in the ecosystem attribute for a site with exotic (haplotype M) Phragmites

750 relative to the native Phragmites subspecies americanus, a minus (-) indicates a decrease in the ecosystem

751 attribute, and an equal sign (=) indicates there was no difference between the exotic and native strains.

\section{$\begin{array}{lll}\text { Variable } & \text { Trend } & \text { Citation }\end{array}$}

\begin{tabular}{|c|c|c|}
\hline Plant biomass & + & $\begin{array}{l}\text { Alldred et al. 2016, Mozdzer et al. 2013, Mozdzer and Megonigal 2012, } \\
\text { Holdredge et al. 2010, Kulmatiski et al. 2010, Rothman and Bouchard 2007, } \\
\text { Saltonstall and Stevenson 2007, League et al. 2006, Ehrenfeld 2003, } \\
\text { Windham 2001, Meyerson et al. 2000a,b, Windham and Lathrop 1999 }\end{array}$ \\
\hline \multirow{2}{*}{$\begin{array}{l}\text { Soil Organic } \\
\text { Matter (SOM) }\end{array}$} & $=$ & Ehrenfeld 2003 \\
\hline & + & Rooth et al. 2003, Nijburg and Laanbroek 1997 \\
\hline \multirow{4}{*}{$\begin{array}{l}\text { Decomposition } \\
\text { rate }\end{array}$} & + & Duke 2015, Mozdzer et al. 2016 \\
\hline & - & Rothman and Bouchard 2007, Windham 2001 \\
\hline & + or - & Ehrenfeld 2003 \\
\hline & - or $=$ & Liao et al. 2008 \\
\hline \multirow{3}{*}{ Biomass $[\mathrm{N}]$} & + & $\begin{array}{l}\text { Alldred et al. 2016, Wang et al. 2015, Mozdzer and Zieman 2010, Packett } \\
\text { and Chambers 2006, Windham and Meyerson 2003, Meyerson et al. 2000a }\end{array}$ \\
\hline & + or - & Ehrenfeld 2003, Windham and Ehrenfeld 2003 \\
\hline & + or $=$ & Rodríguez and Brisson 2015 (- for Biomass $[\mathrm{P}]$ ) \\
\hline \multirow{2}{*}{ Total soil N } & $=$ & Ehrenfeld 2003 \\
\hline & + & Yarwood et al. 2016, Nijburg and Laanbroek 1997 \\
\hline
\end{tabular}




\begin{tabular}{|c|c|c|}
\hline \multirow{3}{*}{$\begin{array}{l}\text { Extractable } \\
\text { inorganic } \mathrm{N} \\
\text { (ammonium, } \\
\text { nitrate) }\end{array}$} & - or $=$ & Ehrenfeld 2003, Meyerson et al. 2000a \\
\hline & & Tulbure and Johnston 2010 \\
\hline & - & Price et al. 2014 (both $\mathrm{NH}_{4}$ and NO ) \\
\hline \multirow{2}{*}{$\begin{array}{l}\text { Mineralization } \\
\text { and } \\
\text { nitrification }\end{array}$} & + & $\begin{array}{l}\text { Ruiz-Rueda et al. 2009, Ehrenfeld 2003, Windham and Ehrenfeld 2003, } \\
\text { Meyerson et al. 2000a }\end{array}$ \\
\hline & + or $=$ & Windham and Meyerson 2003 \\
\hline \multirow{3}{*}{ Denitrification } & + & Alldred et al. 2016, Ruiz-Rueda et al. 2009 \\
\hline & + or $=$ & Ehrenfeld 2003, Windham and Ehrenfeld 2003, Windham and Meyerson 2003 \\
\hline & $=$ & Meyerson et al. 2000a \\
\hline
\end{tabular}

Phosphate $\quad=\quad$ Price et al. 2014, Tulbure and Johnston 2010


Fig. 1

753

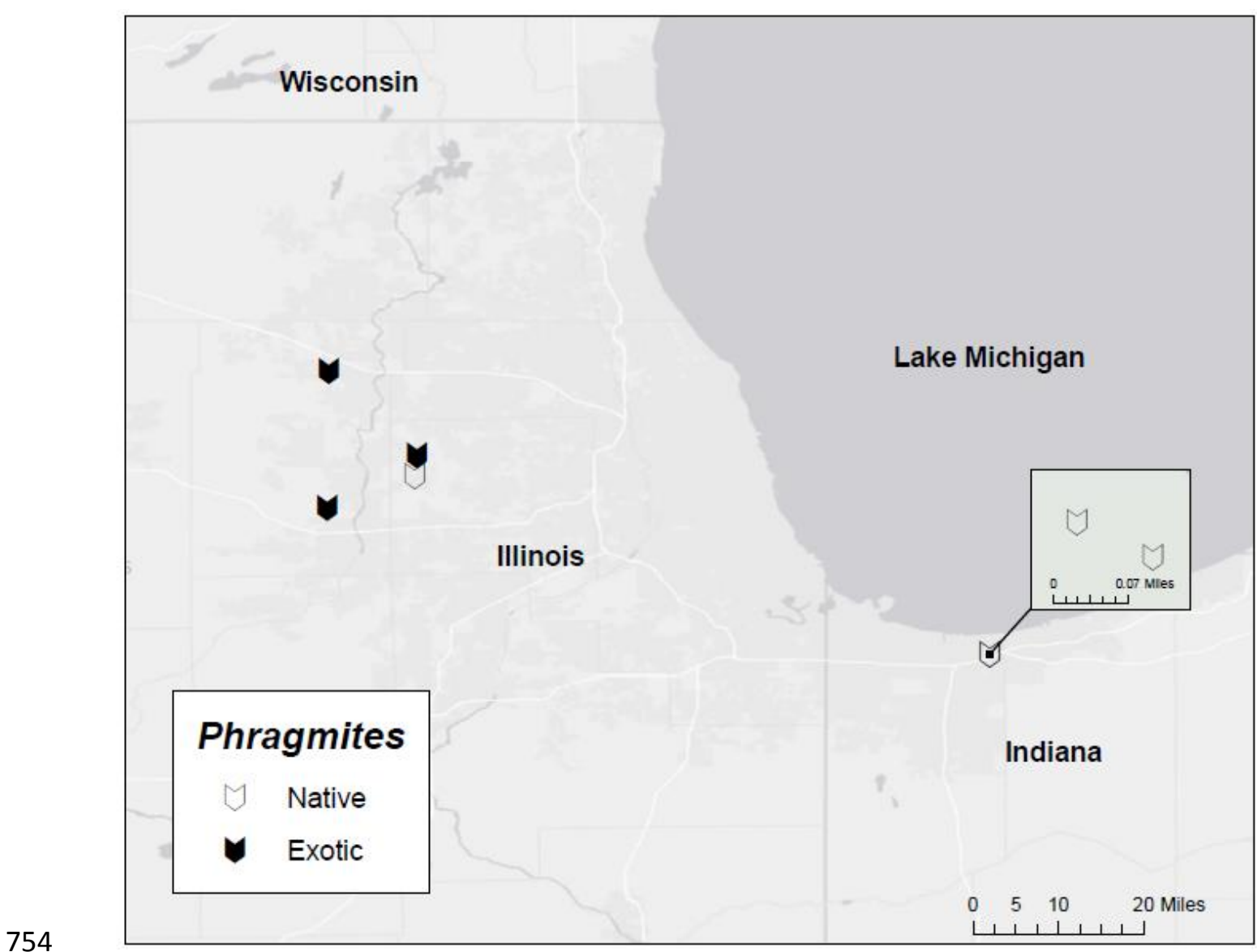


Fig. 2
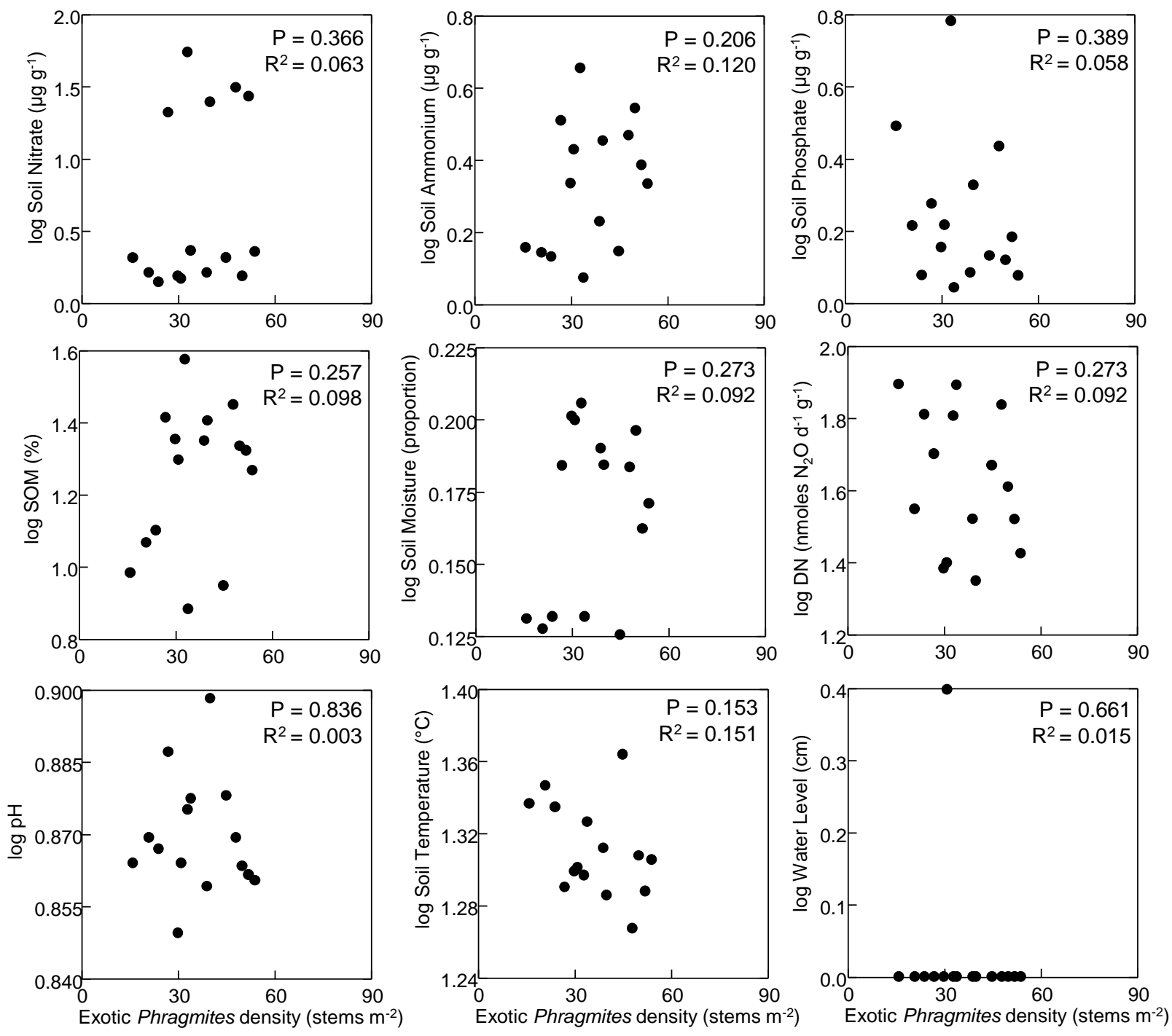
Fig. 3
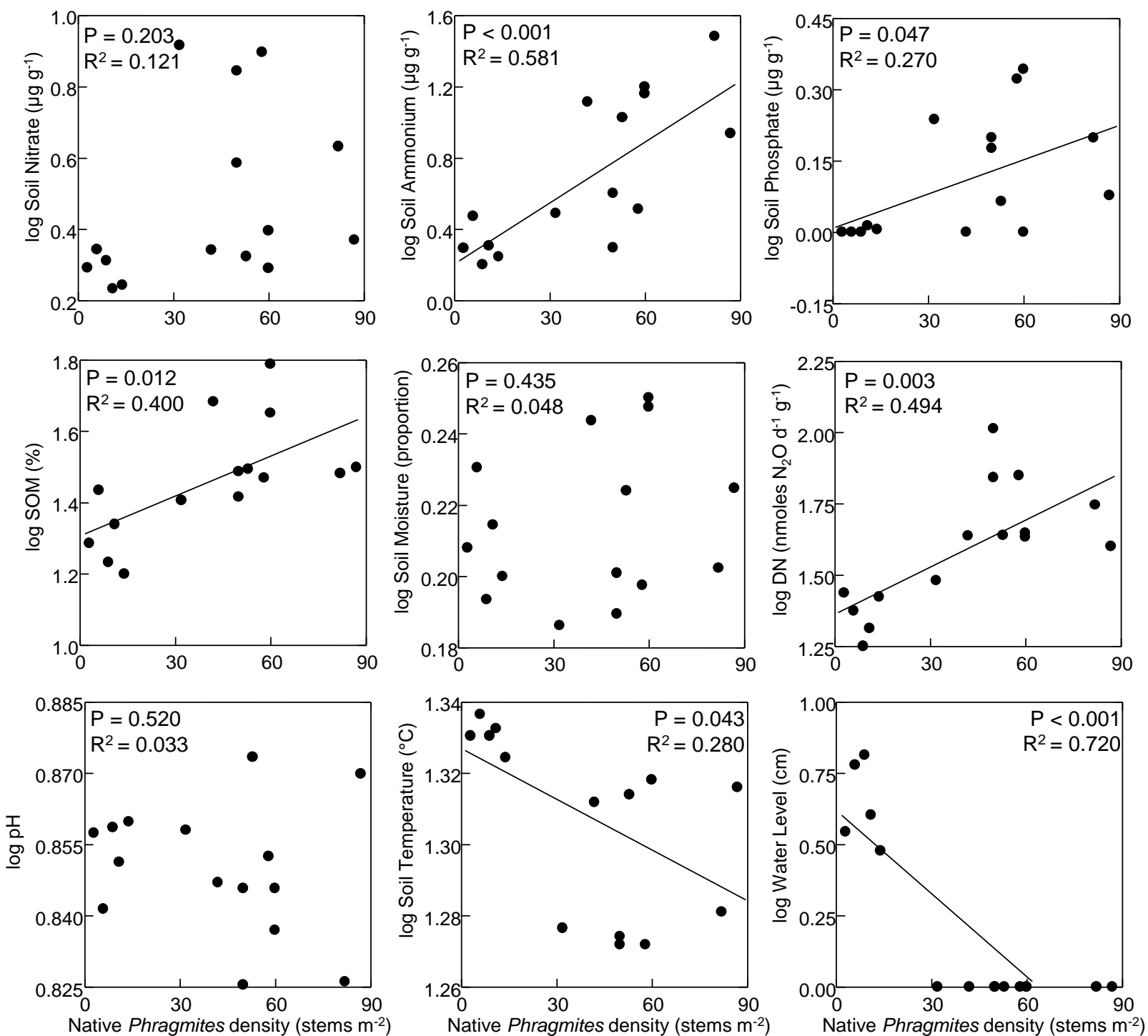
764 Fig. 4
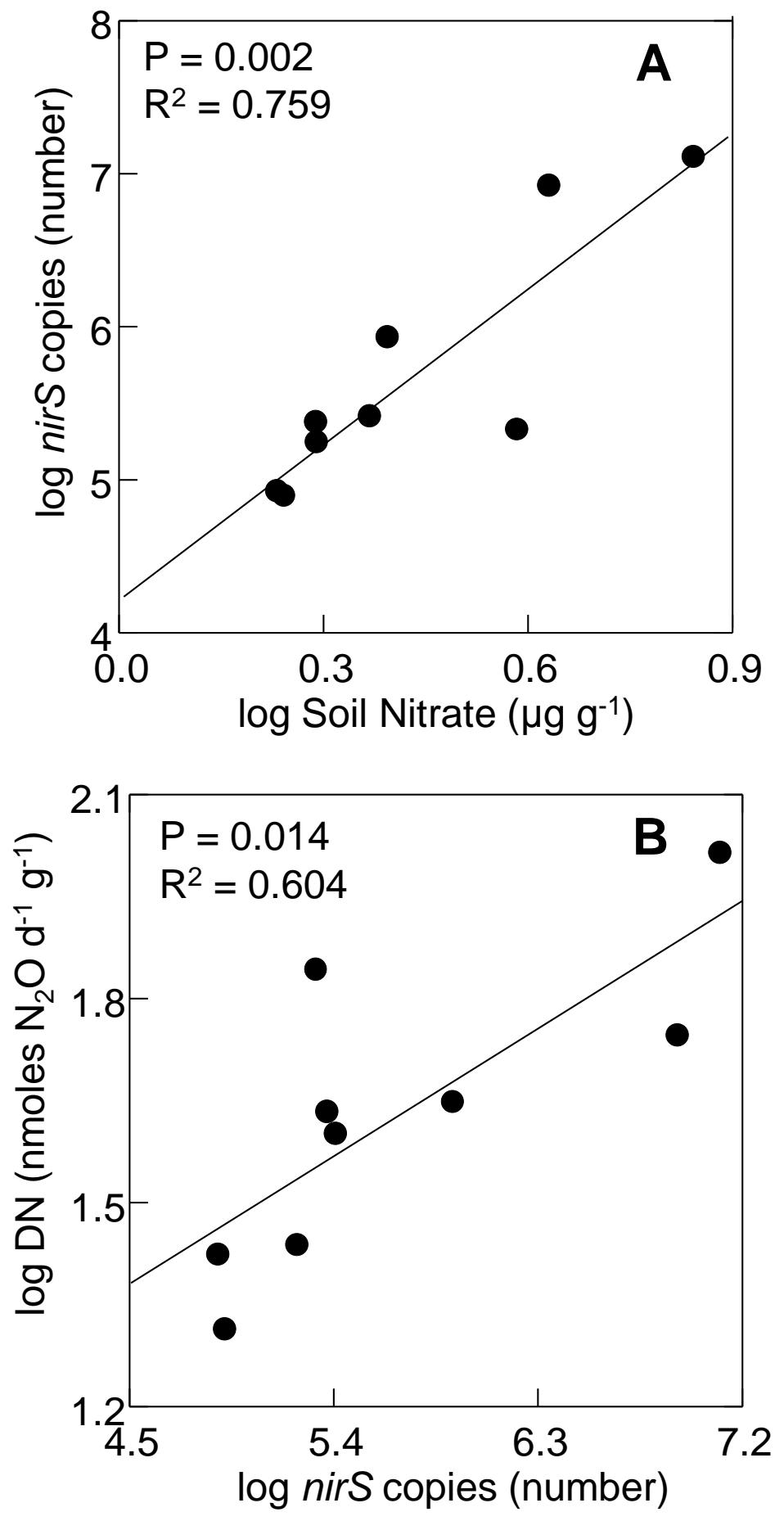
Fig. 5

767
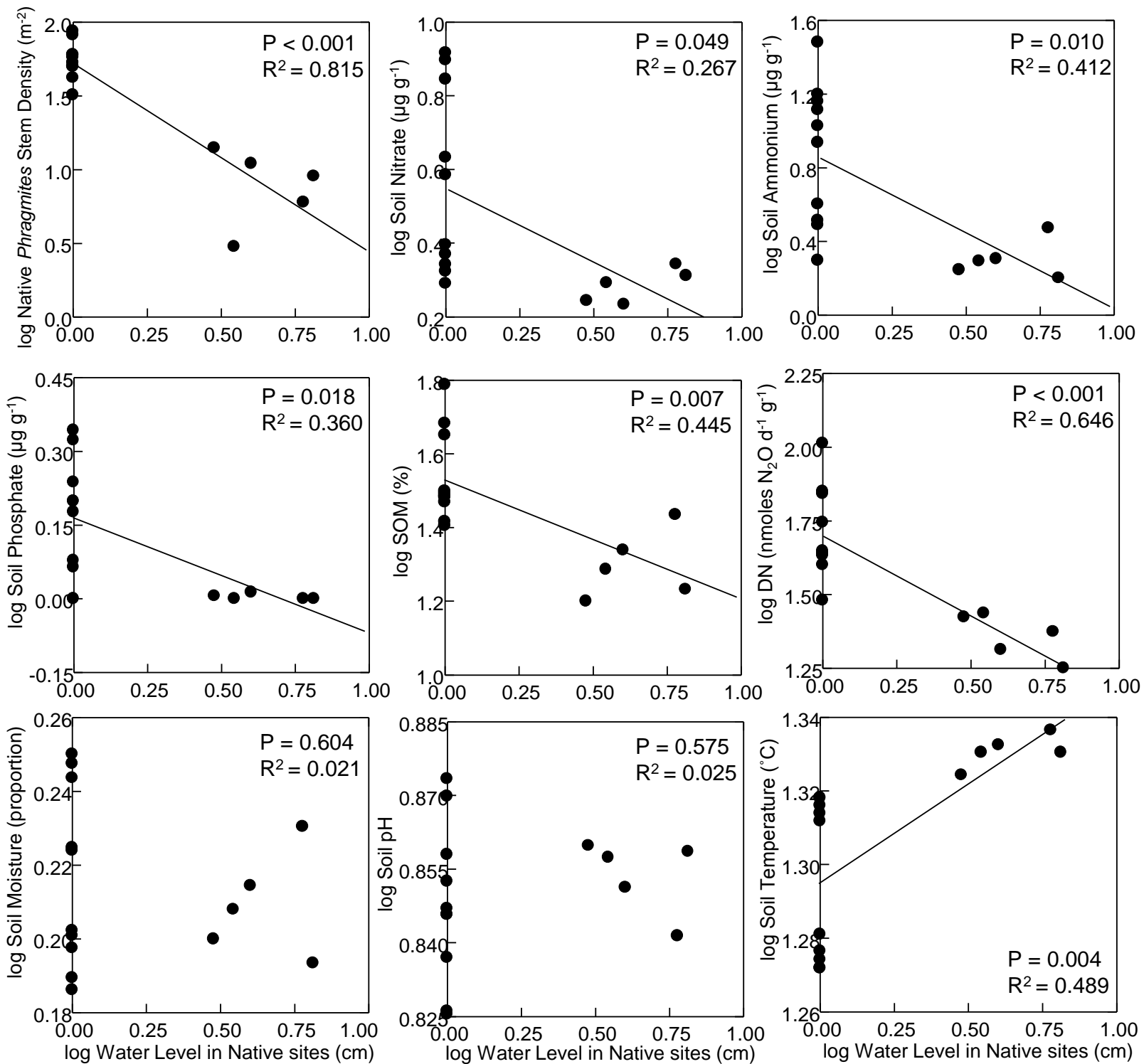